\title{
Long-term effects of gap creation and liming on understory vegetation with a focus on tree re- generation in a European beech (Fagus sylvatica L.) forest
}

\author{
N. Lin, N. Bartsch, T. Vor
}

Lin N., Bartsch N., Vor T., 2014. Long-term effects of gap creation and liming on the understory vegetation with a focus on tree regeneration in a European beech (Fagus sylvatica L.) forest. Ann. For. Res. 57(2): 233-246, 2014.

Abstract. The long-term effects of gap creation and liming on tree regeneration and understory competition were examined in a mature European beech (Fagus sylvatica) stand on a nutrient-poor site. In 1989, trees were felled to create four $30 \mathrm{~m}$ wide circular gaps, and $3 \mathrm{t} \mathrm{ha}^{-1}$ fine dolomite was applied to two of these gaps and the surrounding area, whereas the remaining two gaps and most parts of the stand remained untreated. In 2010, the stand density was 153 trees $\mathrm{x} \mathrm{ha} \mathrm{h}^{-1}$ and the basal area was $29.51 \mathrm{~m}^{2} \mathrm{x} \mathrm{ha}^{-1}$. Testing a factorial combination of two levels of canopy cover (gap and stand) and two levels of lime application (limed and unlimed), the results of the case study partly support our initial hypothesis that the combined or single effects of liming and canopy removal on understory plant communities last for more than 20 years. Some effects disappeared slowly over time, while others did not. Understory vegetation of the unlimed gaps and the limed and unlimed stands was rapidly dominated by beech regeneration, whereas limed gaps were dominated by fireweed (Epilobium angustifolium), bramble (Rubus fruticosus agg.) and raspberry (Rubus ideaus) for around 14 years. There, the density of the beech regeneration was reduced by competitive ground vegetation species. Plant species richness $\left(\mathrm{n} / 100 \mathrm{~m}^{2}\right)$ was still significantly different after 23 years, with an average 10 species per $100 \mathrm{~m}^{2}$ in the limed stand area, 5 species in the unlimed stand area, 25 species in the limed gaps, and only 5 species in the unlimed gaps. Only the combination of liming and canopy removal enhanced the species richness in the long run. On our study site, this combination of liming and canopy opening had a long lasting influence on the ground vegetation in terms of retarding the beech regeneration and enhancing species' richness. Keywords natural regeneration, beech seedling, canopy opening, lime application, ground vegetation, competition, plant biomass.

Authors. Na Lin (na.lin@forst.uni-goettingen), Norbert Bartsch, Torsten Vor Blisgenweg 1, Department of Silvicuture and Forest Ecology of the Temperate Zones, Georg-August University Gottingen, Germany.

Manuscript received August 14, 2014; revised October 09, 2014; accepted November 20, 2014; online first November 27, 2014. 


\section{Introduction}

European beech (Fagus sylvatica L.) is the dominant tree species in central Europe, in part due to a variety of biological characteristics, such as its broad site tolerance, high shade tolerance, prolonged period of height growth increment and the capacity of dominant and predominant trees to expand their crown, and lower palatability to ungulates in the seedling and sapling phase compared to other broadleaved tree species (Leuschner et al. 2004, Bartsch \& Röhrig 2009, Schmidt 2009). However, along with industrial development, soil degradation processes were accelerated by high deposition of acids, nutrients, and heavy metals. High inputs of nitrogen $(\mathrm{N})$ and sulfur (S) caused losses of base cations from soils, especially under nutrient poor site conditions, such as the Solling area in northwestern Germany (Ulrich 1994). A number of studies have been undertaken in the last few decades to analyse nutrient cycling of forest ecosystems (Guckland et al. 2007, Geßler et al. 2007), forest structure (Bengtsson et al. 2000) and functioning (Garcia-Gonzalo et al. 2009, Lindner et al. 2010) under the influence of increasing loads of atmospheric deposition and climate change. Few of these studies have investigated the role of understory plant layers for nutrient budgets following forest disturbances in a long-term perspective (Beckage et al. 2000).

In general, the understory layer and especially tree regeneration is one of the essential components in a forest ecosystem (Gilliam \& Roberts 2003), playing a critical role in the dynamics and functioning of forest ecosystems by influencing long-term successional patterns (Phillips \& Murdy 1985, Abrams \& Downs 1990, Nyland et al. 2006, Royo \& Carson 2006) and contributing to forest nutrient cycling (Chapin 1983, Zak et al. 1990, Anderson \& Eickmeier 2000, Chastain et al. 2006, D'Amato et al. 2009). However, short term effects like the herbaceous biomass acting as a temporary nutrient sink after major disturbance events may also retard the establishment of tree seedlings in the long run. It is still unclear how the nutrient sink effect of understory communities (herbs, shrubs, and tree seedlings and saplings) can be optimized by different forms of forest management, especially in nutrient poor forest ecosystems with long-term high deposition loads of atmospheric pollu-tants (Ulrich 1994, Bartsch 2000). Given the ecological significance in maintaining the structure and functions of forests, we investigate tree regeneration and competing plant species in the understory of a mature European beech forest 23 years after gap creating and liming. In the 1980s, lime application and canopy opening were suggested to aid the establishment of natural beech regeneration under very acidic site conditions. Only a few studies have explained the interactive effects of liming and gap opening on seedling establishment in different forest types: Yang et al. (2012) investigated the interactive effects of gap and liming on seedling growth, and found that in the gaps with lime both yellow birch and sugar maple had higher leaf biomass than in other plots. Gasser et al. (2010) reported that only liming did not increase the density, growth or survival of sugar maple and yellow birch.

We focused on monoculture forest to examine how liming and gap creation influence understorey development in a mature European beech forest over 23 years. Since 1989, some studies have been published from this forest, focusing on nutrient cycling (forest floor decomposition, $\mathrm{C}$ and $\mathrm{N}$ dynamics: Bauhus et al. 1995, 2004), element release (Bartsch 2000, Vor \& Brumme 2002), decay of coarse and fine woody debris (Müller-Using et al. 2009), soil solution (Bartsch 2000), and fine root growth (Bauhus et al. 1996). In this paper we address the following questions: (1) Do gap opening and liming promote natural tree regeneration in the long run? (2) What impacts on plant diversity do the treatments have? (3) Which factor is more important (gap creation vs. liming) for the dynamics of tree regeneration? 


\section{Material and methods}

\section{Study site}

The study site is located in the Solling mountains in northwestern Germany ( $51^{\circ} 46^{\prime} \mathrm{E}, 9^{\circ} 34^{\prime}$ E) at an elevation of $500 \mathrm{~m}$ above sea level. The soil type is a dystric Cambisol and the forest floor type is a typical moder (Bauhus et al. 2004). The climate is humid, with an annual mean temperature of $7{ }^{\circ} \mathrm{C}$, and a mean annual precipitation of $1,100 \mathrm{~mm}$ (Bartsch et al. 2002). The forest community belongs to the Luzulo-Fagetum group (Bartsch \& Röhrig 2009). Characteristics of the European beech (Fagus sylvatica L.) stand were a mean diameter (dbh) of $45.6 \mathrm{~cm}$ and a mean height of 29.7 $\mathrm{m}$ at a basal area of $32.5 \mathrm{~m}^{2}$ and an average stem density of $199 \mathrm{ha}^{-1}$ in 1988 (Akça \& Athari 1992). In 2010 the mean dbh was $48.6 \mathrm{~cm}$, the stand density 153 trees $\cdot \mathrm{ha}^{-1}$ and the basal area $29.5 \mathrm{~m}^{2} \cdot \mathrm{ha}^{-1}$. In 2013 the forest was about 170 years old. Regular silvicultural management (thinning and harvesting) of this 8.17 ha forest stand had ceased in 1967. However, in 1989 groups of trees were felled to create four circular $30 \mathrm{~m}$ wide gaps. After gap creation and removing stems and branches from the gaps 3 $\mathrm{t} \mathrm{ha}^{-1}$ of fine dolomite $\left(10.6 \mathrm{kmol}_{\mathrm{c}} \mathrm{CaCO}_{3} \mathrm{~kg}\right.$ ${ }^{1}, 11 \mathrm{kmol}_{\mathrm{c}} \mathrm{MgCO}_{3} \mathrm{~kg}^{-1}$ ) was scattered in two gaps and their surrounding areas (approx. one tree length, Bauhus \& Bartsch 1995) (Fig. 1). According to the recommended practices at that time, the lime was slightly mixed with the organic horizons by superficial scarification.

\section{Experimental design and data collection}

In order to investigate the effects of lime application and gap creation on tree regeneration and understory vegetation a $2 \times 2$-factorial (two lime levels $\times$ two canopy levels) design

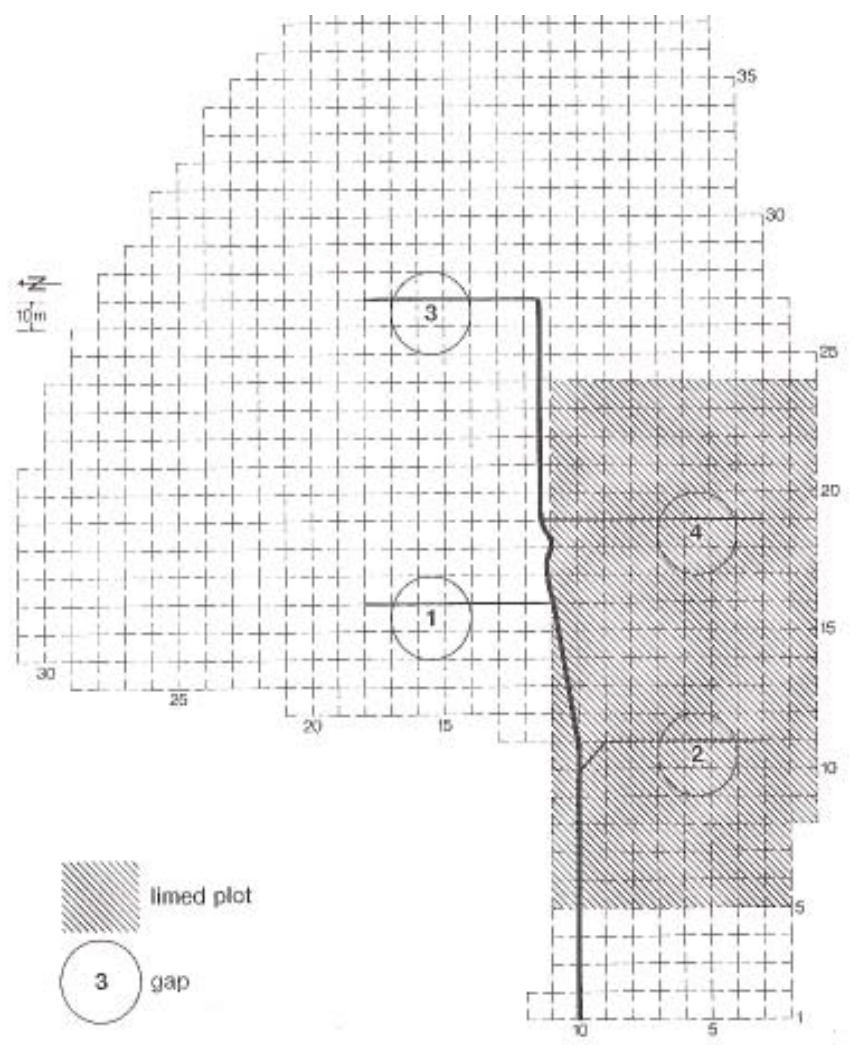

Figure 1 The location of the experimental plots in the study site: Gaps number 1 and 3 were not limed, gaps number 2 and 4 including a surrounding belt were limed 
with two replicates per treatment was applied. Eight plots of $10 \mathrm{~m} \times 10 \mathrm{~m}$ were established and permanently marked after the gap creation in 1989: two unlimed stand parts, two limed stand parts, two unlimed gap centers and two limed gap centers. With the low number of replications, no randomization was possible. However, the size of the plots $\left(100 \mathrm{~m}^{2}\right)$ can compensate for the lack of replication, particularly because the four sites of the gaps were reasonably uniform before the experiment began (Bartsch 2000).

In August and September 2012 the coverage (in \% of the plot area) of all understory plant species was recorded and compared with previous data. For the tree regeneration species, numbers, diameter at breast height (dbh), ground diameter ( $2 \mathrm{~cm}$ above the soil surface) and height (vertical height) were measured in the field, following the same method of vegetation survey as the prior years. For herbaceous plants, the height was only measured for species with cover values $>2 \%$. To estimate the aboveground biomass of herbaceous species and tree seedlings and saplings with a height $\leq 5 \mathrm{~m}$, we used PhytoCalc 1.4 (Bolte et al. 2009, Heinrichs et al. 2010). PhytoCalc 1.4 allows a non-destructive quantification of the dry weight and nutrient pools of understorey plants in forests by using the relationship between the species biomass, cover and mean shoot length (Heinrichs et al. 2010). The model has been successfully validated on independent measurements in several German forest ecosystems (Mölder et al. 2008, Schulze et al. 2009). To estimate the biomass of larger saplings (height $>5 \mathrm{~m}$ ), we felled 30 saplings at ground level, measured their height and dbh and separated them into stems, branches and leaves. The compartments were oven dried at $105{ }^{\circ} \mathrm{C}$ to obtain the dry weight. The data from these 30 trees were used for developing a site specific allometric equation to estimate the total aboveground biomass of European beech seedlings. During the whole sampling period no other understory trees had been present on the study plots.

To compare recent with former surveys we used archived data from the same subplots (data series from 1989 to 2012). All tree seedlings and saplings were additionally recorded in the periods from 1990-1994 and 20002005; vegetation relevés after Braun-Blanquet (1964) were also done in 1991, 1998 and 2005. However, because the tree regeneration was recorded separately no shrub layer (plant height $>0.5 \mathrm{~m}$; $\leq 5 \mathrm{~m}$ ) cover values were assessed from 1991 to 2005. Herbaceous species and shrubs taller than $0.5 \mathrm{~m}$ were assigned to the herb layer (plant height $\leq 0.5 \mathrm{~m}$ ) for this period.

The soil samples were collected using a soil corer with a diameter of $8 \mathrm{~cm}$ in October 1989 , at the locations where gaps were created in the following winter. 96 cores were bulked by mineral soil depth $(0-5,5-10 \mathrm{~cm})$ to form 16 composite samples per layer, four per gap. In 1991, 1996 and 1997, mineral soil $(0-5,5-10 \mathrm{~cm})$ was sampled in the unlimed stand, unlimed gaps, limed gaps, and in limed stand parts with four (1991) or three replicates $(1996,1997)$ per treatment. In October 2011, four replicates were taken for each treatment and soil depth in the stand parts and each gap. These samples were collected along two transects in the gaps and along four transects in the stand parts. The distance between sampling locations was $10 \mathrm{~m}$ in the stand and approximately $2 \mathrm{~m}$ in the gaps. After removing root particles, mineral soil were dried at $40{ }^{\circ} \mathrm{C}$, and sieved $(<2 \mathrm{~mm})$ afterwards. Soil $\mathrm{pH}$ was determined with a glass electrode ( $\mathrm{pH}$ meter, single rod assembly) (Meiwes et al. 1986).

\section{Data analysis}

Homoscedasticity was tested using FlignerKilleen test, and normal distribution was tested using the Shapiro-Wilk test. To test for differences in the understory aboveground biomass between treatments, an ANOVA was used for the data that were collected in 1993, 1998 and 2012. To ascertain differences within the 
shrub, herb and moss layers' species richness, respectively, Tukey-Kramer's HSD test was applied. Differences between factor levels of the regeneration were determined by pairwise Wilcoxon test $(P<0.05)$. All statistical tests were performed with $\mathrm{R}$, version 3.0.1 (R Development Core Team 2013).

\section{Results}

\section{Top soil acidity dynamics}

In the $0-5 \mathrm{~cm}$ soil layer, the soil $\mathrm{pH}$ values were significantly higher than in 1989 in the limed gaps in 1991, 1996, 1997, and 2011 (Table 1). The single effect of canopy opening or liming on top soil layer's $\mathrm{pH}$ was not observed in 2011. At the $5-10 \mathrm{~cm}$ soil, only the canopy opening with liming affected the soil acidity statistical significantly in 1991, 1996, and 1997. In 2011, the $\mathrm{pH}$ values at the 5-10 $\mathrm{cm}$ soil were significantly higher in the limed gap and limed stand than in the unlimed plots.

\section{Tree regeneration dynamics}

The density, heights and base diameters of Eu- ropean beech seedlings were determined from 1990-1994, from 2000-2005 and in 2012 (Fig. 2). Peaks of beech seedling numbers were always found after mast years, but mortality was high due to intra- and interspecific competition. High interspecific competition must have caused a tremendous decline in the seedling numbers in the limed gaps from 1991 to 2005. In 2012 the beech seedlings seem to establish there again (Fig.2).

In 2012, the density of beech seedlings (Table 2) was much higher in limed stand than in untreated closed stand parts (695 seedlings $/ 100 \mathrm{~m}^{2}$ vs. $\left.324 \mathrm{~s} . / 100 \mathrm{~m}^{2}\right)$, but much higher in unlimed gaps $\left(721 \mathrm{~s} . / 100 \mathrm{~m}^{2}\right)$ than in limed gaps $\left(117 \mathrm{~s} . / 100 \mathrm{~m}^{2}\right)$. The difference of Norway spruce (Picea abies) seedlings between unlimed plots and limed plots was also remarkable (Table 2$)$. In the plots $\left(100 \mathrm{~m}^{2}\right)$ of the unlimed stand and unlimed gap the numbers of Norway spruce seedlings both were 23, only 2 Norway spruce seedlings were found in the limed stand and 1 in the limed gap. Goat willow (Salix caprea) only grew in limed gaps, mountain ash (Sorbus aucuparia) only in unlimed gaps.

The effect of the treatments on the beech seedlings and saplings height and diameter

Table 1 Mineral soil pH-values $(\mathrm{KCl})$ at 0-5 cm and 5-10 cm depth in 1989-1991, 1996-1997 and 2011. Archived data from 1989-1997. Different letters indicate significant differences between treatments within one layer ( $p<0.05$, Tukey's HSD test for multiple comparison)

\begin{tabular}{llllll}
\hline & & & limed & & unlimed \\
\cline { 3 - 5 } & year & gap & stand & gap & stand \\
\hline $0-5 \mathrm{~cm}$ & $1989^{*}$ & & & & 2.88 \\
& $1991^{* *}$ & $3.07^{\mathrm{b}}$ & & $2.94^{\mathrm{ab}}$ & $2.89^{\mathrm{a}}$ \\
& $1996^{* * *}$ & $3.31^{\mathrm{c}}$ & $3.01^{\mathrm{bc}}$ & $2.82^{\mathrm{ab}}$ & $2.77^{\mathrm{a}}$ \\
& $1997^{* * *}$ & $3.02^{\mathrm{b}}$ & $2.85^{\mathrm{b}}$ & $2.92^{\mathrm{b}}$ & $2.57^{\mathrm{a}}$ \\
& $2011^{* * * *}$ & $3.15^{\mathrm{b}}$ & $3.01^{\mathrm{a}}$ & $2.98^{\mathrm{a}}$ & $2.97^{\mathrm{a}}$ \\
\hline $5-10 \mathrm{~cm}$ & $1989^{*}$ & & & & 3.15 \\
& $1991^{* *}$ & $3.30^{\mathrm{b}}$ & & $3.17^{\mathrm{ab}}$ & $3.15^{\mathrm{a}}$ \\
& $1996^{* * *}$ & $3.20^{\mathrm{b}}$ & $3.01^{\mathrm{ab}}$ & $2.96^{\mathrm{ab}}$ & $2.90^{\mathrm{a}}$ \\
& $1997^{* * *}$ & $3.06^{\mathrm{a}}$ & $2.89^{\mathrm{a}}$ & $3.20^{\mathrm{a}}$ & $2.75^{\mathrm{a}}$ \\
& $2011^{* * * *}$ & $3.24^{\mathrm{b}}$ & $3.24^{\mathrm{b}}$ & $3.16^{\mathrm{a}}$ & $3.09^{\mathrm{a}}$ \\
\hline
\end{tabular}

Note. Abbreviation: $*_{n}=16$, samples taken before gap creating, $* * n=4$, Tukey's HSD Test, no samples taken from limed stand parts, ${ }^{* * *} \mathrm{n}=3$, Tukey's HSD Test, ${ }^{* * * *} \mathrm{n}=4$ (stand data), $\mathrm{n}=8$ (gap data), Tukey's HSD Test. 


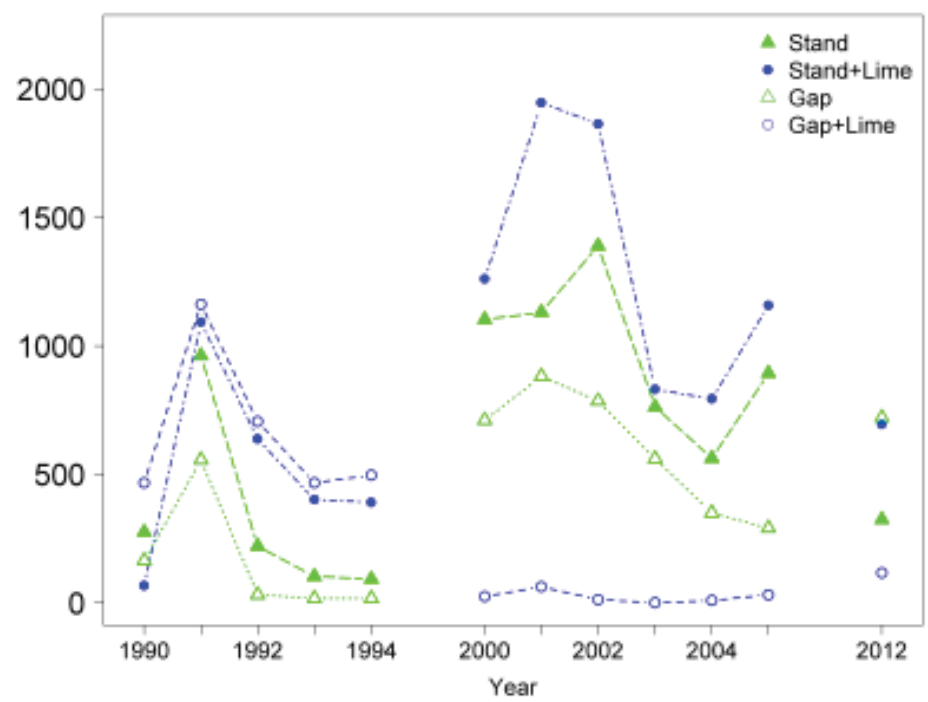

Figure 2 Density of European beech seedlings and saplings in years between 1990 and 2012 in unlimed and limed stand parts and in unlimed and limed gaps. Mean values of all understory beech trees result from two plots each

Table 2 Mean tree seedling abundance per $100 \mathrm{~m}^{2}$ of the shrub layer (height $\left.>0.5 \mathrm{~m} ; \leq 5 \mathrm{~m}\right)( \pm \mathrm{SE})$ in 2012 in unlimed and limed stand parts and in unlimed and limed gaps. The mean values are based on 2 replicates per treatment

\begin{tabular}{|c|c|c|c|c|c|}
\hline \multirow{2}{*}{ treatment } & \multicolumn{5}{|c|}{ Density $\left(\mathrm{n} / 100 \mathrm{~m}^{2}\right)$} \\
\hline & European beech & Norway spruce & Goat willow & Silver birch & Mountain ash \\
\hline stand & $324 \pm 11$ & $23 \pm 11$ & $0 \pm 0$ & $3 \pm 1$ & $0 \pm 0$ \\
\hline gap & $721 \pm 89$ & $23 \pm 11$ & $0 \pm 0$ & $3 \pm 0$ & $4 \pm 0$ \\
\hline limed stand & $695 \pm 97$ & $2 \pm 0$ & $0 \pm 0$ & $0 \pm 0$ & $0 \pm 0$ \\
\hline limed gap & $117 \pm 2$ & $1 \pm 0$ & $16 \pm 6$ & $0 \pm 0$ & $0 \pm 0$ \\
\hline
\end{tabular}

in 2012 is presented in Figure 3. On average, regeneration height differed significantly between treatments $(p<0.05)$. In the unlimed stand parts the highest mean height and diameter values were found $(2.7 \mathrm{~m}$ and $3.5 \mathrm{~cm})$. The beech seedlings in the limed gaps were significantly smaller than in other plots (Fig. 3).

\section{Plant species diversity and cover}

More than 20 years after lime application and canopy removal, there were still some differences of the plant species' diversity, density and cover values between unlimed stands, limed stands, unlimed gaps and limed gaps. In 2012, a total of 32 plant species in the herb, shrub and moss layers were identified at the study sites. The highest plant diversity was found 238 in the limed gaps (Fig. 4). Especially the herb layer's diversity was favored by the conditions in the limed gaps. Both of the single (liming: $p=0.002$, canopy gap: $p=0.012)$ effects, and the combined effect $(p=0.009)$ on the understory plant species' diversity were significant (Table 3). We found 25 plant species in the understory of the limed gaps in 2012, but only 5 species in the unlimed gaps. After 23 years, the species richness is still significantly higher in the limed gap centers than in other plots.

The understory plant cover reached $97.5 \%$ in 2012 in the shrub layer of the unlimed stand parts, $85 \%$ in the limed stand parts, $82.5 \%$ in the unlimed gaps and only $37.5 \%$ in the limed gaps (Table 4). In limed gaps, however, the herbaceous layer's coverage reached $20 \%$ compared to almost no herb layer cover in 

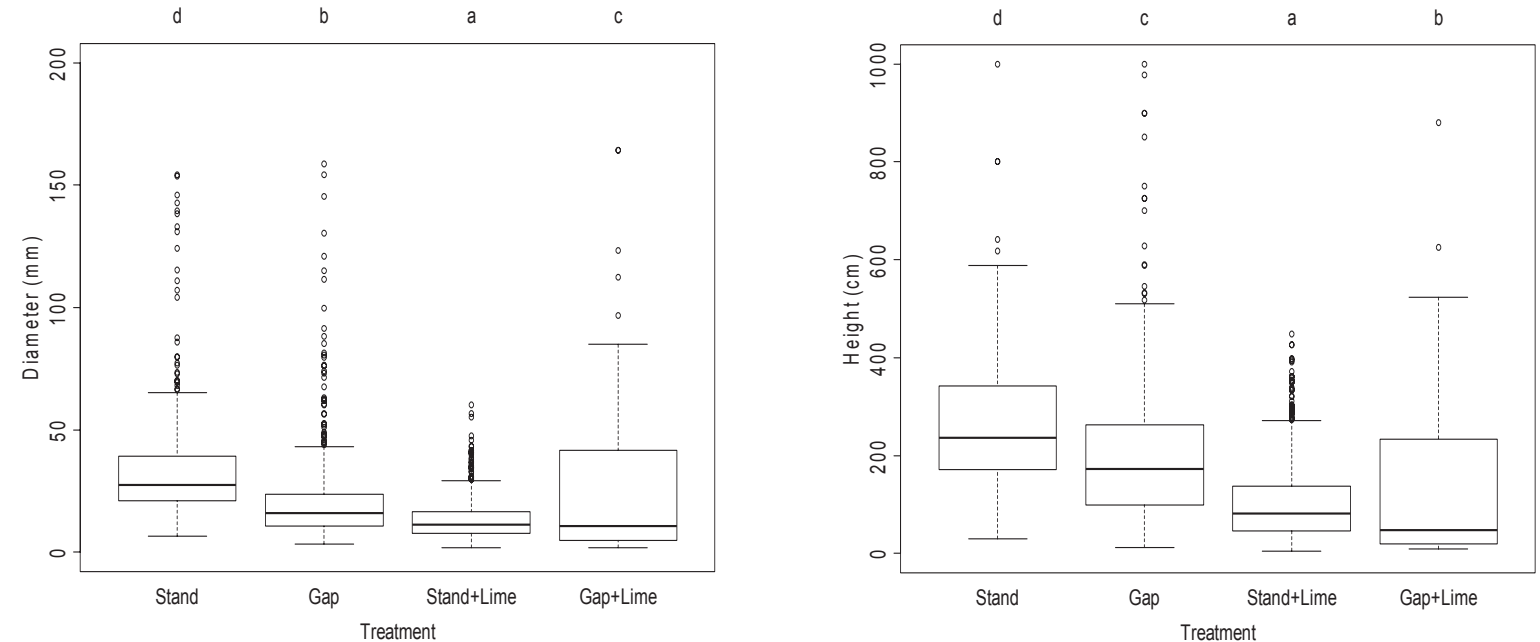

Figure 3 Mean diameter ( $2 \mathrm{~cm}$ above the soil surface) and seedling height (vertical height) of beech seedlings and saplings in 2012 in unlimed and limed stand parts and in unlimed and limed gaps. Significant effects among different treatments are indicated by different letters $(p<0.05$, Pairwise Wilcoxon test)

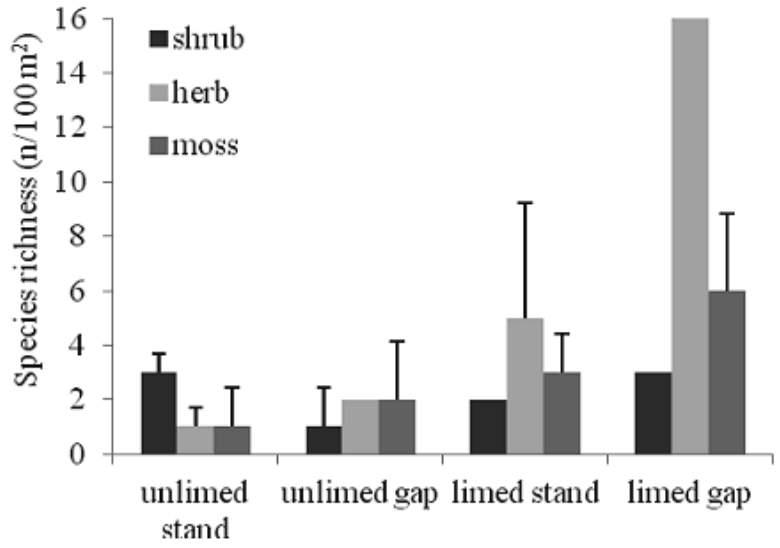

Figure 4 Plant species richness $\left(\mathrm{n} / 100 \mathrm{~m}^{2}\right)$ in the shrub, herb and moss layer 23 years after different treatments of a European beech forest in the Solling area, Germany. Shrub layer height $>0.5 \mathrm{~m} ; \leq 5 \mathrm{~m}$; herb layer $\leq 0.5$ $\mathrm{m}$. Error bars are standard errors of estimates

other plots. Mosses covered the plots only up to $1.5 \%$. This different dynamics is very interesting, because we found the totally opposite trend in the first years after setting up the experiment, with higher cover values in the limed plots (Table 4).

Looking at individual species dynamics, a vigorous growth of herbs, dominated by fireweed (Epilobium angustifolium) was observed in the limed gaps in the year following liming. Liming caused high nitrification rates (Vor \& Brumme 2002), in combination with higher radiation other nitrophilous species like Taraxacum officinale, Urtica dioica, Epilobium montanum and Gynmocarpium dryopteris occurred in the limed gaps. In 1998, there was a marked decrease of Epilobium angustifolium and Epilobium montanum cover values in the limed gaps, and the woody species Salix caprea, Sorbus aucuparia, Populus tremula, Betula pendula, Rubus idaeus and the herbaceous species Urtica dioica took over. Rubus idaeus showed up right after lime application. Its coverage increased from 1991 to 2005, and decreased again after 2005. In 2005, Rubus fruticosus appeared mainly in the limed plots, and covered large parts of the limed gap centers. However, in 2012, it had almost disappeared again. Many species were only temporarily found in the limed and unlimed gaps, and were no longer present in 2012. Some character-species like Luzula luzuloides were always present in all plots.

The number of herbaceous species decreased from 1991 to 2012 in all but the limed gap plots, while the number of mosses increased slightly in the same period (Table 4). Untreated 
Table 3 Treatment effect on the understory species diversity in 2012. Results from ANOVA

\begin{tabular}{lllll}
\hline & 2012 & & & \\
\hline Treatment & MS & df & $F$ & $P$ \\
Liming & 312.5 & 1 & 46.3 & $0.002^{* *}$ \\
Gap & 128 & 1 & 18.96 & $0.012^{*}$ \\
Liming $\times$ Gap & 144.5 & 1 & 21.41 & $0.009^{* *}$ \\
\hline
\end{tabular}

Note. Abbreviations: MS - mean square, df - degrees of freedom, $F$ - variance ratio, $P$ - level of significance, ${ }^{*}$ significance codes: $* * p \leq 0.01, * p \leq 0.05$.

Table 4 Plant cover (\%) ( \pm SE) of the understory layer in 1991, 1993, 1998, 2005 and 2012. Mean values from two $(1991-2005,2012)$ replicates $\left(100 \mathrm{~m}^{2}\right.$ plots $)$ per treatment. Shrub layer height $>0.5 \mathrm{~m} ; \leq 5$ $\mathrm{m}$; herb layer $\leq 0.5 \mathrm{~m}$

\begin{tabular}{|c|c|c|c|c|c|c|c|c|c|}
\hline & \multirow[b]{2}{*}{ layer } & \multicolumn{2}{|l|}{ Stand } & \multicolumn{2}{|l|}{ Gap } & \multicolumn{2}{|l|}{ Stand+Lime } & \multicolumn{2}{|l|}{ Gap+Lime } \\
\hline & & $\begin{array}{l}\text { Species } \\
\left(\mathrm{n} / 100 \mathrm{~m}^{2}\right)\end{array}$ & $\begin{array}{l}\text { Total } \\
\text { cover } \\
(\%)\end{array}$ & $\begin{array}{l}\text { species } \\
\left(\mathrm{n} / 100 \mathrm{~m}^{2}\right)\end{array}$ & $\begin{array}{l}\text { Total } \\
\text { cover } \\
(\%)\end{array}$ & $\begin{array}{l}\text { Species } \\
\left(\mathrm{n} / 100 \mathrm{~m}^{2}\right)\end{array}$ & $\begin{array}{l}\text { Total } \\
\text { cover } \\
(\%)\end{array}$ & $\begin{array}{l}\text { species } \\
\left(\mathrm{n} / 100 \mathrm{~m}^{2}\right)\end{array}$ & $\begin{array}{l}\text { Total } \\
\text { cover }(\%)\end{array}$ \\
\hline & Shrub & - & - & - & - & - & - & - & - \\
\hline \multirow[t]{2}{*}{1991} & Herb & $6 \pm 1$ & $3.5 \pm 3.1$ & $8 \pm 2$ & $5.6 \pm 1.2$ & $12 \pm 1$ & $42.3 \pm 18.9$ & $12 \pm 0$ & $52.3 \pm 2.2$ \\
\hline & Moss & $1 \pm 0$ & $0.6 \pm 0.4$ & $1 \pm 0$ & $5.3 \pm 3.3$ & $1 \pm 1$ & $0.1 \pm 0.1$ & $1 \pm 0$ & $0.2 \pm 0$ \\
\hline \multirow[t]{4}{*}{1993} & Shrub & - & - & - & - & - & - & - & - \\
\hline & Herb & $1 \pm 0$ & $10.0 \pm 5.4$ & $7 \pm 2$ & $30.4 \pm 1.3$ & $13 \pm 0$ & $88.2 \pm 5$ & $10 \pm 0$ & $95.9 \pm 0$ \\
\hline & Moss & $5 \pm 1$ & $1.0 \pm 2.5$ & $3 \pm 3$ & $0.2 \pm 0.1$ & $1 \pm 0$ & $0.2 \pm 0$ & $1 \pm 1$ & $0.1 \pm 0.1$ \\
\hline & Shrub & - & - & - & - & - & - & - & - \\
\hline \multirow[t]{3}{*}{1998} & Herb & $5 \pm 1$ & $14.3 \pm 0.5$ & $17 \pm 1$ & $11.2 \pm 5.1$ & $14 \pm 1$ & $68 \pm 20$ & $14 \pm 2$ & $86 \pm 15.0$ \\
\hline & Moss & $1 \pm 1$ & $0.2 \pm 0$ & $1 \pm 0$ & $11.5 \pm 7.5$ & $1 \pm 0$ & $3.2 \pm 0.5$ & $1 \pm 0$ & $2.9 \pm 0.4$ \\
\hline & Shrub & - & - & - & - & - & - & - & - \\
\hline \multirow[t]{3}{*}{2005} & Herb & $4 \pm 1$ & $19.5 \pm 5.4$ & $13 \pm 2$ & $99.1 \pm 10.7$ & $12 \pm 5$ & $138.6 \pm 21.9$ & $11 \pm 2$ & $181.8 \pm 32.4$ \\
\hline & Moss & $1 \pm 0$ & $0.9 \pm 0.2$ & $1 \pm 0$ & $4.2 \pm 0.6$ & $2 \pm 0$ & $3 \pm 0.4$ & $1 \pm 0$ & $2.2 \pm 1.8$ \\
\hline & Shrub & $3 \pm 1$ & $97.5 \pm 2$ & $1 \pm 0$ & $82.5 \pm 7.5$ & $2 \pm 0$ & $85 \pm 10$ & $3 \pm 1$ & $38 \pm 7$ \\
\hline \multirow[t]{2}{*}{2012} & Herb & $1 \pm 1$ & $0.5 \pm 0$ & $2 \pm 1$ & $1 \pm 0.5$ & $5 \pm 2$ & $1 \pm 0$ & $16 \pm 7$ & $20 \pm 2.5$ \\
\hline & Moss & $1 \pm 1$ & $1 \pm 0.5$ & $2 \pm 1$ & $1.5 \pm 1$ & $3 \pm 1$ & $1 \pm 0$ & $6 \pm 2$ & $1.5 \pm 0.5$ \\
\hline
\end{tabular}

Note. From 1991-2005 the shrub layer was separately described by tree regeneration surveys. Herbs taller than $0.5 \mathrm{~m}$ were assigned to the herb layer during this period. Values $>100 \%$ result from multiple sub layers.

plots (unlimed stands) had the lowest diversity of herbaceous species.

\section{Aboveground biomass dynamics}

The tree regeneration biomass (Table 5) in the treatments were highest in 2012 (unlimed stand: $1095 \mathrm{~g} \mathrm{~m}^{-2}$, unlimed gap center: 702 $\mathrm{g} \mathrm{m}^{-2}$, limed stand: $371 \mathrm{~g} \mathrm{~m}^{-2}$, and limed gap center: $253 \mathrm{~g} \mathrm{~m}^{-2}$ ), and the biomasses of other plant species were highest in 1993 (unlimed gap center: $315 \mathrm{~g} \cdot \mathrm{m}^{-2}$, limed stand: $546 \mathrm{~g} \cdot \mathrm{m}^{-2}$, and limed gap center: $1155 \mathrm{~g} \cdot \mathrm{m}^{-2}$ ) except for at unlimed stand. In the limed gap center, the tree regeneration biomass in 1993 was none, and it increased gradually, from 0 to $8.7 \mathrm{~g} \cdot \mathrm{m}^{-2}$ in 1996 to $252.8 \mathrm{~g} \cdot \mathrm{m}^{-2}$ in 2012 , and the other plant species biomass in limed gap center dynamics in the otherwise way, it decreased.

We compared the understory above ground biomasses from 1993, 1996 and 2012, using a factorial analysis model. The different influences of canopy removal and lime application were obvious in 1993 and in 2012 (Table 6). In 1993, 4 years after soil liming and canopy removal, the canopy effect $(p=0.010)$ and 
the combination of canopy and soil effect $(p$ $=0.038$ ) on the above ground biomass were significantly positive. The soil treatment alone had no significant effect ( $p=0.821)$. After 23 years, only the soil effect ( $p=0.004)$ was significant, but now negatively.

\section{Discussion}

\section{Liming and gap effects on tree regeneration}

At the beginning of treatments application, liming and the combination of liming and gap could enhance the beech regeneration estab- lishment. This is because the availability of light, water and nutrients are important factors governing the development of the tree regeneration. Liming and gap opening reduced the soil acidity and improved the light availability. In this study, lime application enhanced the soil $\mathrm{pH}$ for more than 20 years (Table 1). Earlier, it has been demonstrated that liming and canopy opening accelerated the nutrient cycle at the same site (Bauhus et al. 2004).

We counted and measured European beech seedlings and saplings during three periods from 1990 to 2012. After an initial establishment in all plots it became obvious that the beech seedlings developed differently according to

Table 5 Aboveground biomass partitioning $( \pm$ SE) between tree regeneration and other plants in 1993, 1996, and 2012

\begin{tabular}{cllll}
\hline & \multicolumn{2}{l}{ Tree regeneration* } & \multicolumn{2}{l}{ Other plant species** } \\
\cline { 2 - 5 } Block & $\mathrm{g} / \mathrm{m}^{2}$ & $\%$ & $\mathrm{~g} / \mathrm{m}^{2}$ & $\%$ \\
\hline Unlimed stand & $11.3 \pm 16.9$ & $65.2 \pm 12.5$ & $1.2 \pm 3.8$ & $35.8 \pm 29.1$ \\
Unlimed gap center & $23.82 \pm 24.7$ & $0.7 \pm 0.4$ & $315.2 \pm 62.3$ & $93.0 \pm 6.0$ \\
1993 Limed stand & $47.1 \pm 43.1$ & $7.9 \pm 1.1$ & $546.4 \pm 54.4$ & $92.1 \pm 1.4$ \\
Limed gap center & $0 \pm 0$ & $0 \pm 0$ & $1155.0 \pm 63.0$ & $100 \pm 2.6$ \\
\hline Unlimed stand & $4.3 \pm 2.1$ & $20.6 \pm 19.1$ & $16.6 \pm 16.5$ & $79.4 \pm 39.9$ \\
Unlimed gap center & $11.3 \pm 1.8$ & $27.5 \pm 6.0$ & $29.8 \pm 4.3$ & $72.5 \pm 6.0$ \\
Limed stand & $21.9 \pm 8.2$ & $19.9 \pm 1.4$ & $92.0 \pm 34.0$ & $80.1 \pm 1.4$ \\
Limed gap center & $8.7 \pm 5.7$ & $3.5 \pm 2.6$ & $240.2 \pm 24.2$ & $96.5 \pm 2.6$ \\
\hline Unlimed stand & $1094.8 \pm 41.4$ & $100.0 \pm 1.0$ & $0.2 \pm 0$ & $0.0 \pm 0.0$ \\
Unlimed gap center & $702.2 \pm 27.4$ & $99.7 \pm 4.9$ & $2.1 \pm 0.6$ & $0.3 \pm 0.0$ \\
Limed stand & $371.9 \pm 69.7$ & $99.7 \pm 0.0$ & $1.1 \pm 0.2$ & $0.3 \pm 0.0$ \\
Limed gap center & $252.8 \pm 68.2$ & $89.1 \pm 12.5$ & $31.1 \pm 12.5$ & $10.9 \pm 6.5$ \\
\hline
\end{tabular}

Note. * Fagus sylvatica, Picea abies, Betula pendula, Salix caprea, Sorbus aucuparia, Acer pseudoplatanus.

** Agrostis tenuis, Athyrium filix-femina, Avenella flexuosa, Blechnum spicant, Calamagrostis arundinacea, Calamagrostis epigejos, Caluna vulgaris, Cardamine hirsuta, Carex canescens, Carex divulsa, Carex leporina, Carex ovalis, Carex pallescens, Carex pilulifera, Carex remota, Carex spec., Circaea lutetiana, Dactylis glomerata, Deschampsia cespitosa, Deschampsia flexuosa, Dryopteris carthusiana, Dryopteris dilatata, Dryopteris filix-mas, Epilobium angustifolium, Epilobium montanum, Festuca altissima, Frangula alnus, Galium hercynicum, Galium odoratum, Geranium robertianum, Gymnocarpium dryopteris, Holcus mollis, Impatiens noli-tangere, Impatiens parviflora, Juncus effusus, Scrophularia nodosa, Listera ovata, Luzula luzuloides, Maianthemum bifolium, Moehringia trinervia, Molinia caerulea, Mycelis muralis, Oxalis acetosella, Paris quadrifolia, Poa nemoralis, Poa trivialis, Polygonatum verticillatum, Populus tremula, Pteridium aquilinum, Rubus fruticosus, Rubus idaeus, Rumex spp., Sambucus nigra, Sambucus racemosa, Scrophularia nodosa, Senecio vulgaris, Stellaria media, Taraxacum officinale, Trientalis europaea, Urtica dioica, Vaccinium myrtillus, Veronica officinalis. 
microclimatic and competition effects from other tree species. Due to profound differences in growth forms and mechanisms of reproduction, tree regeneration generally responds to such disturbances (natural and anthropogenic disturbances) in distinct ways, with characteristic traits for each species and differing from herbaceous plants (Gilliam 2007). We could confirm such differences between woody and herbaceous plants. Apart from the beginning and the end of our study period from 1989 to 2012 the limed gaps did not provide favorable conditions for beech seedlings, but for many herbaceous plant species (Table 6). This was surprising, because previous studies showed that large canopy gaps and liming had positive effects on the growth of tree seedlings (Gray \& Spies 1997, Moore et al. 2008, 2012). Looking at the first years of the experiment, liming and improved light conditions had indeed positive effects on the recruitment of the beech regeneration (Fig. 1).

However, from 1994 to 2000 the beech seedling density declined in the limed gaps, unlike the other plots. The explanation for this can be found in the development of other, very competitive plant species like bramble and raspberry in the limed gaps. These plant species were obviously able to outcompete beech regeneration under these growth conditions for a long time. This phenomenon has rarely been reported for beech forests. Mountford et al. (2006) reported that the center of a large gap was almost completely covered by bramble and scarcely covered by natural regeneration. This was supported by Kelemen et al. (2012) who found that a dense cover of Rubus fruticosus L. and Calagrostis epigejos can hamper natural regeneration in large gaps. It was also interesting that single specimens of other tree species developed better under these conditions (e.g. goat willow and trembling aspen), while others grew better without liming (e.g. rowan and spruce). For the spruce regeneration it must be considered that the nearest seed sources are closer to the unlimed gaps, at least partly explaining the higher spruce seedling density there. For the other tree species this possible reason cannot be confirmed. Obviously these species germinated immediately after gap creation and seized the opportunity to grow up before beech trees occupied the plot.

\section{Liming and gap effects on herbaceous layer species diversity}

23 years after the canopy removal and lime application the cover values of the herb layer were significantly higher in limed gaps compared to the other treatments. Single treatments influenced the herb layer's species diversity in a different way. In our study, the number of species in the herb layer was highest 9 years after starting the experiment, except for the limed gaps, where the highest plant diversity was found after 23 years. Similar to others our results have shown that the herbaceous layer can develop immediately after opening the canopy,

Table 6 ANOVA table for the factorial analysis of herb and shrub layers' above ground biomass, with two levels of soil condition (unlimed and limed) and two levels of canopy closure (gap and stand) in 1993, 1996 and 2012

\begin{tabular}{lllllllllllll}
\hline & 1993 & \multicolumn{1}{c}{1996} & \multicolumn{1}{c}{2012} \\
\cline { 2 - 12 } Treatment & MS & df $F$ & $P$ & MS & df $F$ & $P$ & MS & df $F$ & $P$ \\
\hline Soil & 73 & 1 & 0.06 & 0.821 & 640049 & 1 & 0.92 & 0.339 & 652653 & 1 & 33.65 & $0.004^{* *}$ \\
Canopy & 26080 & 1 & 20.69 & $0.010^{*}$ & 1288381 & 1 & 1.85 & 0.176 & 115104 & 1 & 5.93 & 0.072 \\
Soil $\times$ Canopy & 11763 & 1 & 9.33 & $0.038^{*}$ & 698363 & 1 & 1.00 & 0.318 & 45481 & 1 & 2.36 & 0.200 \\
\hline
\end{tabular}

Note. Abbreviations: MS - mean square, df - degrees of freedom, $F$ - variance ratio, $P$ - level of significance, *significance codes: ** $p \leq 0.01, * p \leq 0.05$. 
responding to changing light and microhabitat conditions (Bratton 1976, Whigham 2004). In our study, the shade-intolerant raspberry was an important component of the shrub layer. It emerged after lime application and canopy removal in 1991, and in limed stands and gaps its coverage increased with time. Several studies from temperate forests reported consistently to our results a positive relationship between the herbaceous plant diversity and the light availability in the understory, suggesting that there are fewer shade-tolerant than light-demanding species (Ewald 2003). Canopy gaps are characterized by the temporary increase in the availability of light, water and nutrient supply (Yang et al. 2012). Beatty (2003) also pointed out that one of the factors that contribute to the maintenance of species diversity in forests is the spatial heterogeneity of the forest environment, which is also enhanced by small-scale canopy gaps. Depending on the type of disturbance the species composition and diversity of the herb layer can either return rapidly after a disturbance, or remain impoverished for a long period (Gilliam 2003, 2007). The forest ground vegetation is mainly influenced by tree competition for light and water. Therefore canopy gaps are essential for many plant species to be able to establish in the forest understory. According to Ewald (2003), species richness is, apart from light conditions, closely linked to soil $\mathrm{pH}$, because only a limited number of plant species are adapted to very acid soil conditions.

\section{Liming and gap effects on the aboveground biomass of natural tree regeneration and herbaceous plants}

23 years after the treatments we found that the seedlings and ground vegetation at the limed sites developed in this way: (1) in the centre of the limed gaps, bramble covered most of the beech seedlings and outcompeted them for a long time, but some of the few present were among the tallest, most upright and fast- est growing; (2) towards the edges of the gaps bramble cover was slightly less; beech seedlings were moderately abundant but patchy, generally smaller, and growing more plagiotropic compared to the unlimed gap centre; (3) in the limed stand parts bramble was much less abundant; opposite to beech seedlings. However, beech seedlings were much smaller in the stand parts than in the gaps due to the worse light conditions. In the unlimed gaps, there were only beech seedlings without other ground vegetation. Liming obviously promoted the establishment of herbaceous vegetation. Although liming increased the resilience of the system with regard to the disruption of nitrogen cycling because it promoted the establishment of herbaceous vegetation, it was not beneficial for the recruitment of beech seedlings in the long run. Gasser et al. (2010) also mentioned that vegetation control might have a beneficial effect for sugar maple regeneration in the gaps. The positive response of the understory aboveground biomass to liming and canopy opening would have been expected given the observed significant effects on the light and chemical soil conditions such as increased soil $\mathrm{pH}$, cation exchange capacity, and the element concentrations in the soil solution (Bartsch 2000, Bauhus 1994). Some other studies confirmed that improving the light conditions in forest stands lead to a higher understory biomass (Sabo et al. 2009, Ares et al. 2010, Jonard et al. 2010). However, in our study, canopy effects on the understory aboveground biomass were only significant in 1993 (Table 6). We argue that the main understory plants in a beech forest are young beech seedlings or saplings, because European beech is one of the most shade tolerant climax species that is able to regenerate successfully even in small gaps (Röhrig 1991). This would explain that light effects on the understory aboveground biomass were not significant in our case. The liming treatment alone had no significant effect either four or nine years after lime application, respectively $(P=0.821$ and 0.339$)$. However, after 23 
years the soil effect $(P=0.004)$ on the understory aboveground biomass was significantly negative. As described above we assume that the positive effect of liming on the growth of highly competitive herb and shrub species retarded the growth of the tree regeneration, and therewith the accumulation of biomass. The competitive effect of herbaceous plants on tree regeneration is most likely caused by reduced soil water availability (Knoop \& Walker 1985, Gordon et al. 1989, Davis et al. 1999).

\section{Conclusions}

Although we are aware that this is only a case study at one site we try to draw the following conclusions: Liming in combination with canopy opening affected the understory plant growth in different ways over more than two decades. (1) at the beginning liming and canopy opening promoted the tree regeneration establishment, however, along with the development of other plant species in the limed gaps, the beech regeneration was outcompeted; (2) the plant cover and the understory biomass was also negatively affected in the long term by the lime treatment after an intitial positive signal; (3) the liming and gap opening led to a decrease of the soil acidity over two decades; (4) in the long run, the gap opening alone was beneficial for the development of natural $\mathrm{Eu}$ ropean beech regeneration; (5) The positive effect of the combination of liming and canopy opening on species diversity was lasting more than 20 years.

\section{Acknowledgements}

This research was financially supported by the China Scholarship Council from 2011 to 2014 and by the German BMBF from 1991 to 1994 and from 1996 to 1999 . We would like to thank Steffi Heinrichs for the vegetation relevés and Ulrike Westphal, Michael Unger, Karl-Heinz
Heine, and Andreas Parth for other field and lab assistance.

\section{References}

Abrams M.D., Downs J.A., 1990. Sucessional replacement of old-growth white oak by mixed mesophytic hardwoods in southwestern Pennsylvania. Canadian Journal of Forest Research 20: 1964-1870. DOI: 10.1139/x90250.

Anderson W.B., Eickmeier W.G., 2000. Nutrient resorption in Claytonia virginiaca L.: implications for deciduous forest nutrient cycling. Canadian Journal of Botany 78: 832-839 DOI: 10.1139/b00-056.

Akça A., Athari S., 1992. Biomasse Entwicklung in einem Buchenwaldökosystem in der Phase des Stickstoffvorratsabbaus. In Berichte des Forschungszentrums Waldökosysteme, Universität Göttingen, Reihe B, Bd. 31: 386-389.

Ares A., Neill A.R., Puettmann K.J., 2010. Understory abundance, species diversity and functional attribute response to thinning in coniferous stands. Forest Ecology and Management 260: 1104-1113.

Bartsch N., 2000. Element release in beech (Fagus sylvatica L.) forest gaps. Water Air Soil Poll 122: 3-16. DOI: $10.1023 / \mathrm{A}: 1005265505479$.

Bartsch N., Röhrig E., 2009. Management options for European beech forests in relation to changes in $\mathrm{C}$ - and $\mathrm{N}$ Status as described by the three study sites. In: Brumme R., Khanna P.K. (eds.) Functioning and management of European beech ecosystems. Ecological Studies 208: 425-456. Berlin: Springer-Verlag.

Bartsch N., Bauhus J., Vor T., 2002. Effects of group selection and liming on nutrient cycling in a European beech forest on acidic soil. In: Dohrenbusch A., Bartsch N. (eds.), Forest development-succession, environmental stress and forest management. Springer-Verlag, Berlin, pp. 109-144.

Bauhus J., 1994. Stoffumsätze in Lochhieben. Dissertation, Georg-August-Universität Göttingen.

Bauhus J., Bartsch N., 1996. Fine root growth in beech (Fagus sylvatica L.) forest gaps. Canadian Journal of Forest Research 26: 2153-2160. DOI: 10.1139/ x26244.

Bauhus J., Vor T., Bartsch N., Cowling A., 2004. The effects of gaps and liming on forest floor decomposition and soil $\mathrm{C}$ and $\mathrm{N}$ dynamics in a Fagus sylvatica forest. Canadian Journal of Forest Research 34: 509-518. DOI: 10.1139/ x03-218.

Bauhus J., Bartsch N., 1995. Mechanisms for carbon and nutrient release and retention in beech forest gaps. I. Microclimate, water balance and seepage water chemistry. Plant Soil 168-169, 579-584. DOI: 10.1007/ BF00029371.

Beatty S.W., 2003. Habitat heterogeneity and maintenance of species in understory communities. In: Gilliam F.S., 
Robets M.R. (eds.), The Herbaceous Layer in Forests of Eastern North America, New York: Oxford University Press. pp 177-197.

Beckage B., Clark J.S., Clinton B.D., Haines B.L., 2000. A long-term study of tree seedling recruitment in southern Appalachian forests: the effects of canopy gaps and shrub understories. Canadian Journal of Forest Research 30: 1617-1631. DOI: 10.1139/x00-075.

Bengtsson J., Nilsson S.G., Franc A., Menozzi P., 2000. Biodiversity, disturbances, ecosystem function and management of European forests. Forest Ecology and Management 132: 39-50.

Bolte A., Czajkowski T., Bielefeldt J., Wolff B., Heinrichs S., 2009. Schätzung der oberirdischen Biomassevorräte des Baum- und Strauchunterwuchses in Wäldern auf der Basis von Vegetationsaufnahmen. Forstarchiv 80: 222-228.

Bratton S.P., 1976. Resource division in and understory herb community: Responses to temporal and microtopographpic gradients. American Naturalist 110: 679693. DOI: $10.1086 / 283097$.

Braun-Blanquet J., 1964. Pflanzensoziologie, 3. Aufl.,Springer-Verlag, Wien. DOI: 10.1007/978-37091-8110-2.

Chapin F.S., 1983. Nitrogen and phosphorus nutrition and nutrient cycling by evergreen and deciduous understory shrubs in an Alaskan black spruce forest. Canadian Journal of Forest Research 13: 773-781. DOI: 10.1139/ x83-107.

Chastain R.A., Currie W.S., Townsend P.A., 2006. Carbon sequestration and nutrient cycling implications of the evergreen understory layer in Appalachian forests. Forest Ecology and Management 231: 63-77.

D'Amato A.W., Orwig D.A., Foster D.R., 2009. Understory vegetation in old-growth and second-growth Tsuga canadensis forests in western Massachusetts. Forest Ecology and Management 257: 1043-1052.

Davis M.A., Wrage K.J., Reich P.B., Tjoelker M.G., Schaeffer T., Muermann C., 1999. Survival, growth, and photosynthesis of tree seedlings competing with herbaceous vegetation along a water-light-nitrogen gradient. Plant Ecology 145: 341-350. DOI: 10.1023/ A:1009802211896.

Ewald J., 2003. The calcareous riddle: why are there so many calciphilous species in the central European flora? Folia Geobotanica 38: 357-366. DOI: 10.1007/ BF02803244.

Garcia-Gonzalo J., Peltola H., Brice-nõ-Elizondo E., Kellomäãki S., 2007. Effects of climate change and management on timber yield in boreal forests, with economic implications: A case study. Ecological Modelling 209: 220-234. DOI: 10.1016/j.ecolmodel.2007.06.021.

Gasser D., Messier C., Beaudet M., Lechowicz M.J., 2010. Sugar maple and yellow birch regeneration in response to canopy opening, liming and vegetation control in a temperate deciduous forest of Quebec. Forest Ecology and Management 259, 2006-2014. DOI: 10.1016/ j.foreco.2010.02.011.
Geßler A., Keitel C., Kreuzwieser J., Matyssek R., Seiler W., Rennenberg H., 2007. Potential risks for European beech (Fagus sylvatica L.) in a changing climate. Trees 21: 1-11. DOI: 10.1007/s00468-006-0107-x.

Gilliam F.S., Roberts M.R., 2003. The dynamic nature of the herbaceous layer: synthesis and future directions for research. In: Gilliam F.S., Roberts M.R. (eds) The herbaceous layer in forests of Eastern North America, New York: Oxford University Press. pp 323-337.

Gilliam F.S., 2007. The ecological significance of the herbaceous layer in temperate forest ecosystems. BioScience 57: 845-858. DOI: 10.1641/B571007.

Gordon D.R., Welker J.M., Menke J.W., Rice K.J., 1989. Competition for soil water between annual plants and blue oak (Quercus douglasii) seedlings. Oecologia 79: 533-541. DOI: 10.1007/BF00378672.

Gray A.N., Spies T.A., 1997. Microsite controls on tree seedling establishment in conifer forest canopy gaps. Ecology 78: 2458-2473. DOI: 10.1890/00129658(1997)078[2458:MCOTSE]2.0.CO;2.

Guckland A., Jacob M., Flessa H., Thomas F.M., Leuschner Ch., 2009. Acidity, nutrient stocks, and organicmatter content in soils of a temperate deciduous forest with different abundance of European beech (Fagus sylvatica L.). Journal of Plant Nutrition and Soil Science 172: 500-511. DOI: 10.1002/jpln.200800072.

Heinrichs S., Bernhardt-Römermann M., Schmidt W., 2010. The estimation of aboveground biomass and nutrient pools of understorey plants in closed Norway spruce forests and on clearcuts. European Journal of Forest Research 129 (4): 613-624. DOI: 10.1007/ s10342-010-0362-7.

Jonard M., André F., Giot P., Weissen F., Van der Perre R., Ponette Q., 2010. Thirteen-year monitoring of liming and PK fertilization effects on tree vitality in Norway spruce and European beech stands. European Journal of Forest Research 6: 1203-1211. DOI: 10.1007/s10342010-0410-3.

Kelemen K., Mihók B., Gálhidy L., 2012. Dynamic response of herbaceous vegetation to gap opening in a central European beech stand. Silva Fennica 46: 53-66. DOI: $10.14214 /$ sf.65.

Knoop T., Walker B.H., 1985. Interactions of woody and herbaceous vegetation in a southern African Savanna. Journal of Ecology 73 (1): 235-253. DOI: $10.2307 / 2259780$.

Leuschner C., Hertel D., Schmid I., Koch O., Muhs A., Hölscher D., 2004. Stand fine root biomass and fine root morphology in old-growth beech forests as a function of precipitation and soil fertility. Plant Soil 258: 43-56. DOI: 10.1023/B:PLSO.0000016508.20173.80.

Lindner M., Maroschek M., Netherer S., Kremer A., et al. 2010. Climate change impacts, adaptive capacity, and vulnerability of European forest ecosystems. Forest Ecology and Management 259: 698-709. DOI: 10.1016/ j.foreco.2009.09.023.

Meiwes K.J., Khanna P.K., Ulrich B., 1986. Parameters for describing soil acidification and their relevance to sta- 
bility of forest ecosystems. Forest Ecology and Management 15:161-179. DOI: 10.1016/0378-1127(86)900642.

Moore J.D., Duchesne L., Ouimet R., 2008. Soil properties and maple-beech regeneration a decade after liming in a northern hardwood stand. Forest Ecology and Management 255: 3460-3468. DOI: 10.1016/ j.foreco.2008.02.026.

Moore J.D., Ouimet R., Duchesne L., 2012. Soil and sugar maple response 15 years after dolomitic lime application. Forest Ecology and Management 281: 130-139. DOI: 10.1016/j.foreco.2012.06.026.

Mountford E.P., Savill P.S., Bebber D.P., 2006. Patterns of regeneration and ground vegetation associated with canopy gaps in a managed beechwood in southern England. Forestry 79: 389-408. DOI: 10.1093/forestry/cpl024.

Mölder A., Bernhardt-Römermann M., Schmidt W., 2008. Herb-layer diversity in deciduous forest: Raised by tree richness or beaten by beech? Forest Ecology and Management 256: 272-281. DOI: 10.1016/ j.foreco.2008.04.012.

Müller-Using S., Bartsch N., 2009. Decay dynamic of coarse and fine woody debris of a beech (Fagus sylvatica L.) forest in Central Germany. European Journal of Forest Research 128: 287-296. DOI: 10.1007/s10342009-0264-8.

Nyland R.D., Bashant A.L., Bohn K.K., Verostek J.M., 2006. Interference to hardwood regeneration in northeastern North America: Ecological characteristics of American Beech, Striped Maple, and Hubble bush. Northern Journal of Applied Forestry 23: 53-61.

Phillips D.L., Murdy W.H., 1985. Notes: effects of Rhododendron (Rhododendron maximum L.) on regeneration of Southern Appalachian hardwoods. Forest Science 31: 226-233.

Röhrig E., 1991. Vegetation structure and forest succession. In: Röhrig E., Ulrich B. (eds.), Temperate deciduous forests. Elsevier, Amsterdam, pp 35-49.

Royo A.A., Carson W.P., 2006. On the formation of dense understory layers in forests worldwide: consequences and implications for forest dynamics, biodiversity, and succession. Canadian Journal of Forest Research 36: 1345-1362. DOI: 10.1139/x06-025.

Sabo K.E., Sieg C.H., Hart S.C., Bailey J.D., 2009. The role of disturbance severity and canopy closure on standing crop of understory plant species in ponderosa pine stands in northern Arizona, USA. Forest Ecology and Management 257:1656-1662.

Schmidt W., 2009. Vegetation. In: Brumme R., Khanna P.K. (eds.) Functioning and management of European beech ecosystems. Ecological Studies 208: 65-86. Schulze E.D., Luyssaert S., Ciais P., Ciais A., Freibauer I.A., Janssens I.A., et al., 2009. Importance of methane and nitrous oxide emissions for Europe's terrestrial greenhouse gas balance. Nature Geoscience 2: 842-850. DOI: 10.1038/ngeo686.

Ulrich B., 1994. Nutrient and acid-base budgets of central European forest ecosystems. In: Godbold D.L., Hüttermann A. (eds.), Effects of acid rain on forest processes. Wiley, New York, pp. 231-264.

Vor T., Brumme R., 2002. N2O losses result in underestimation of in situ determinations of net $\mathrm{N}$ mineralization. Soil Biology \& Biochemistry 34: 541-544. DOI: 10.1016/S0038-0717(01)00190-0.

Whigham D.F., 2004. Ecology of woodland herbs in temperate deciduous forests. Annual Review of Ecology, Evolution, and Systematics 35: 583-621. DOI: 10.1146/ annurev.ecolsys.35.021103.105708.

Yang G., Chen H., Cheng S., et al., 2012. Interactive effects of canopy gap, liming and understory control on aboveground growth of yellow birch and sugar maple seedlings. Ekoloji 21: 1-8. DOI: 10.5053/ ekoloji.2012.841.

Zak D.R., Grigal D.F., Gleeson S., Tilman D., 1990. Carbon and nitrogen cycling during old-field succession: Constraints on plants and microbial biomass. Biogeochemistry 11: 111-12. DOI: 10.1007/ BF00002062. 